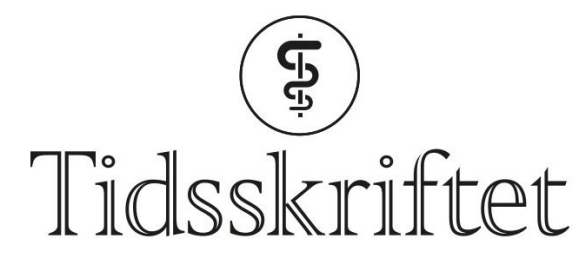

DEN NORSKE LEGEFORENING

\title{
De som trenger oss mest
}

MINILEDER

ARE BREAN

Sjefredaktør

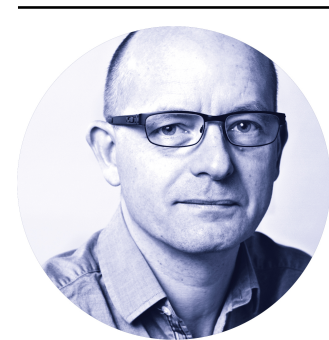

Tilgang til lik medisinsk hjelp er ikke en realitet for alle i Norge i dag. Den kanskje mest sårbare gruppen i landet - papirløse migranter - er nemlig unntatt. Det sørger et nasjonalt regelverk for. Det slår fast at deres rett til helsehjelp er begrenset til øyeblikkelig hjelp og helsehjelp som ikke kan vente.

Legens plikt til å hjelpe er helt grunnleggende i vår yrkesetikk. Både menneskerettighetene og den universelle legeeden slår fast at medisinsk hjelp skal baseres på behov, ikke på status. Når nasjonalt regelverk strider mot dette, settes leger og andre helsearbeidere i en umulig skvis. Derfor har Legeforeningen, Sykepleierforbundet og Psykologforeningen gått sammen om et felles opprop. Der oppfordres norske myndigheter til å gi papirløse mennesker reell tilgang til helsehjelp, basert på helsefaglige vurderinger, yrkesetikk og menneskerettigheter. Det handler om rettighetene til noen av de aller mest behovstrengende blant oss. Vi i Tidsskriftet støtter oppropet. Gi din signatur, du også: www.papirlose.org.

Publisert: 6. mai 2019. Tidsskr Nor Legeforen. DOI: 10.4045/tidsskr.19.o8.01

(C) Tidsskrift for Den norske legeforening 2020. Lastet ned fra tidsskriftet.no 